\title{
Willingness to Pay More to Stay at a Boutique Hotel with an Environmental Management System. A Preliminary Study in Spain
}

\author{
Laura Fuentes-Moraleda $^{1, *(\mathbb{D})}$, Carmen Lafuente-Ibáñez ${ }^{2}{ }^{\mathbb{D}}$, Ana Muñoz-Mazón ${ }^{1}{ }^{(\mathbb{C}}$ and \\ Teresa Villacé-Molinero ${ }^{1}$ (D) \\ 1 Business Administration Department, Faculty of Social Sciences and Law, Rey Juan Carlos University, \\ Paseo Artilleros s/n. Vicálvaro, 28032 Madrid, Spain; ana.munoz@urjc.es (A.M.-M.); \\ teresa.villace@urjc.es (T.V.-M.) \\ 2 Legal and Business Science Faculty, Francisco de Vitoria University, 28223 Madrid, Spain; \\ mcarmen.lafuente@ufv.es \\ * Correspondence: laura.fuentes@urjc.es
}

Received: 13 July 2019; Accepted: 14 September 2019; Published: 19 September 2019

\begin{abstract}
Since 1990, both people's recognition of the need for sustainability around the world and environmental management systems in the tourism industry have been growing. Academic studies have primarily focused on the willingness of consumers to pay more to stay in major hotel chains, finding that the incorporation of environmental management systems (EMSs) is a way to save money by reducing costs, while improving the image and competitive advantage of these chains in the market. However, the aggregate environmental impact of tourism activity does not only depend on the practices of industry leaders. It also relates to the degree to which all stakeholders adopt these practices. Boutique hotels fall under the category of small-sized accommodation and are characterized by their size, independent management, and respect for the local environment. Hotel consumers display positive attitudes with respect to green hotel practices, which provides a starting point for motivating hotels to continue working on improving their environmental impact performance. For this reason, the objective of this paper is to determine whether boutique hotel clients are willing to pay more for a hotel with an environmental management system. Two dependence techniques are applied, logit regression and linear regression. The results show that the respondents' age and income, as well as the strength of their environmental commitment, are determinant factors of whether clients would pay more to stay in a boutique hotel with an EMS. This preliminary study tries to investigate the "willingness to pay" in the Spanish boutique hotels. The originality of this article responds to the demand for a more holistic perspective on the hospitality sector, contributing to the understanding of hotel clients and their willingness to pay more for an EMS.
\end{abstract}

Keywords: environmental management system; boutique hotel; willingness to pay more; environmental commitment; millennials

\section{Introduction}

Hotels are major tourism actors and; therefore, cause heavy environmental impacts, because they affect the sustainability of the place in which they are developed and operated through the consumption of natural resources [1]. Since the early nineties, tourism companies, especially companies in the hotel industry, have signed onto different voluntary initiatives to demonstrate their commitment to sustainability, such as the study of Buffa et al. [2]. These initiatives include [3] (i) codes of conduct, (ii) better environmental practices, (iii) ecolabelling and awards, (iv) environmental management systems, and (v) environmental performance indicators. There is an increasing influence on the 
value to hoteliers of taking further steps towards promoting their green practices [4]. This practice is known as green hospitality, and it has become more and more important, given that is no longer a niche movement, but rather a mainstream current [4,5]. Additionally, hotels now recognize that an eco-friendly reputation can enable them to target environmentally-conscious customers, gain differentiation advantages, and yield premium prices for their services [6]. Most existing research focuses on the institution of environmental management systems in major hotel chains [7], but very few studies have examined EMSs implementation in micro-, small-, and medium-sized hotels [8]. In the tourism business, aggregate environmental impact and per-capita impact do not depend on the good practices of tourism industry leaders alone, but also on the extent to which good practices are adopted across the board [9]. That is to say, it is important to observe not only the behavior of the major chains, but also the behavior of other lodging providers, who account for quite a large share of the industry. More research on the application of EMSs in small and independently-managed hotels is needed, and environmental organizations should focus their efforts on such research, which typically lacks professional help and sufficient funding [10]. On the other hand, and from the consumer point of view, it is very important for the consumer or tourist to feel like a stakeholder in the environmental certification introduction process [11]. Additionally, one of the main factors affecting the incorporation of sustainable measures in accommodation enterprises is an environmentally-conscious clientele $[9,10]$. Therefore, consumers with environmental commitments could be a strong motivation for hotels to improve their environmental performance $[12,13]$.

Among the small lodging providers, the growth of the boutique hotel sector internationally has been widely reported $[14,15]$. Moreover, boutique hotels have been expanding, despite setbacks caused by the economy [16]. More than a decade ago, a key note market report on hotels [17] related this growth to consumers searching for a more unique or special hotel and indicated that, rather than simply viewing the hotel as accommodation, clients consider the hotel an experience in itself [14]. According to Taylor [18], this growth is associated with the fact that travelers are willing to pay more at a boutique hotel, and with this in mind, hotel groups are "jumping into the game". Many major hotel companies are garnering the best of boutiques, and some of them are introducing boutique-style hotels. Boutiques will remain relevant; even as large hotel companies introduce their own versions. The fact that the big hotel companies are introducing brands that are trying to be unique is certainly a sign that this is now an established product line. In London, the townhouse and boutique segment was the highest performing sector in 2016 [19].

In the case of Spain, tourism activity represents 12\% of the GDP [20], and in 2017, a total of 81.7 million tourists visited Spain, which represents an increase from the previous year of $8.6 \%$. According to the data, Spain is the second most visited country in the world [21] (UNWTO, 2018). Such growth spurred scholars early on to examine the impact of tourism and the measures that tourism managers can take to mitigate the negative impact of tourism and maximize its positive impact. In this context, sustainability forms the paradigm that must be maintained in order to balance out the positive and negative impacts of tourism on society, the economy, and the environment [22]. In Spain, "boutique hotel" is not an official classification, as it is in other countries, so there are no official statistics on the number of boutique hotels. Boutique hotels are characterized, first, by their small size, with fewer than 100 rooms [23] and, in many cases, fewer than 50 rooms. They also have a unique, innovative design $[15,19,24]$ that tends to tie in with the destination's signature characteristics and the region's history and culture [25]. Moreover, personalized services and privacy are fundamental characteristics of boutique hotels $[15,24]$. In order to approximate the number of these establishments, we have revised the information given by the most popular specific commercial platforms. The website, rusticae.com, contains 197 hotels; boutiquehotel.me provides 285 boutique hotels in Spain; selectahotels.com provides 220 boutique hotels; and greatsmallhotels.com provides 333 hotels. The hospitality specialist news service, Hosteltur [26], reported that, in 2005, there were 133 boutique hotels in Spain, so the number has more than doubled in the last ten years. 
There are three reasons for this study. First, and despite the importance of EMSs in accommodation in relation to making the industry more sustainable [24], small and medium establishments do not implement EMSs, most of the time for economic reasons. Studies of consumers' willingness to pay can give small hotels a motivation to continue working and improving their environmental practices $[4,12,13]$. The second reason is that no evidence has been found on studies focusing on the consumers' willingness to pay more to stay at a boutique hotel with sustainable practices. Finally, the study focuses on Spain, a leading country in tourism, where boutique hotels have grown very fast over the last years.

Due to the importance of the implementation of EMSs in hotels, specifically for small ones, and the relevance of boutique hotels in Spain, this paper strives to respond to the call for research in order to bridge this gap. The present work is focused on the boutique hotel sector (independently owned and managed), which has often appeared to be forward thinking concerning particular interests, such as environmental awareness [4]. This study contributes to a theoretical and practical understanding of the relevance of sustainability in relation to the small accommodation sector, a sector whose sustainability needs have rarely been articulated in the literature. It is informed by one main research question:

RQ1. Are boutique hotel clients willing to pay more for a hotel with an environmental management system?

This main contribution to the literature of the present study is its analysis of the willingness of boutique accommodation consumers to pay more for a hotel with an environmental management system, which would imply a step forward in travelers' knowledge of this particular segment and their predisposition toward environmental management systems in boutique hotels. The study is the first stage of an investigation about the "willingness to pay" in the Spanish boutique hotels. The information that this research brings to light is of great interest for industry entrepreneurs, quality clubs, and the managers of environmental management systems, who can use it to design their products and optimize their commercial efforts.

\section{Theoretical Background: Willingness to Pay More (WTP) for Sustainable Practices in the Accommodation Industry}

\subsection{The Willingness to Pay More (WTP) for Environmental Management Systems in Boutique Hotels}

Boutique hotels cannot afford to enter a price competition with multinational hotel chains because of their size, but on the other hand, their small size can be highly advantageous, because they are able to provide a superior service [27] (p. 27). Boutique hotels could choose an alternative EMS approach, because of the associated branding recognition, consumer preferences, and appealing to environmentally-conscious clients [4,28].

While there is no specific research on whether boutique hotel customers would be willing to pay more for environmental certification, there are some studies related to the topic. Boley and Uysal [28] analyze competitive synergy by practicing triple bottom-line sustainability applied to an independently-owned boutique hotel. In this specific case study, the authors confirm that the perceptions of a green hotel from the ground-up, as well as a client type who favors the setting of a sustainable business philosophy, could further add to the intangible assets of the property.

Kleinrichert et al. [4] study the extent to which environmental management systems have been introduced into boutique hotels. Their study on technology, social media, and green practices presents an interesting analysis of the web promotion of two boutique hotels, and their use of international versus regional legitimation of their environmental practices.

\subsection{Tourists' Environmental Awareness and WTP for Hotels with Sustainable Practices}

The last decade has seen many studies on consumers' willingness to pay for green hotels $[8,13,29,30]$. Previous academic research shows that travelers' level of environmental awareness and lifestyle can 
influence their willingness to pay more (WTP) for sustainable or environmentally-certified products. In their study, Kuminoff et al. [31] propose this as an important line of work. That is to say, they call for further study on whether the travelers who visit hotels that incorporate sustainable practices do so in order to be consistent with their lifestyle. For Han et al. [32], this is one of the variables that differentiate clients who would pay more for a hotel with sustainable practices from those who would not.

Numerous studies on the environment have investigated in depth and verified the impact of environmental awareness on decision-making [33-35]. Environmental awareness is associated with individuals' sensitivity to environmental degradation, limited resources, and pollution $[12,36]$ and is reflected in their consumer decisions [36].

There is previous literature that analyze how consumers' environmental awareness is related to their willingness to pay more (WTP) for sustainable practices [37-39]. This paper employs the theory of planned behavior (TPB) [33,40-42] to analyze individuals' attitudes relating to green behavior. Travelers' environmental awareness level and lifestyle can influence their willingness to pay more for sustainable or environmentally-certified products $[28,29,43]$.

Regarding this theory, and based on previous studies [12,23], the variables that authors include in their study on calibrating consumers' environmental behavior and awareness are: Recycling, energy, and water saving and the consumption of products that have a low impact on pollution. All these arguments support the first hypothesis (H1):

Hypothesis 1 (H1). Clients who are more environmentally aware would be willing to pay more to stay at a boutique hotel that has an environmental management system.

\subsection{Tourists' Personal Characteristics and WTP for Hotels with Sustainable Practices}

According to Kim and Han [33], beyond the simple application of TPB to hospitality product purchasing activity, variables that explain customers' decision-making, in both green hotel and hospitality contexts, should be added. In this sense, the authors proposed the inclusion of variables related to personal characteristics. In this connection, Han et al. [40] also indicate that it might be meaningful to test the proposed model by considering the effects of personal characteristics (e.g., gender, age, education, and income), as other studies have done in the past [35].

In order to be considered ecologically conscious, consumers should be able to identify the relevant ecological effects of their consumption [44]. The knowledge and skills required for particular actions, the availability of time, and general capabilities and resources (such as literacy, money, social status, and power) are included under this concept. Additionally, sociodemographic variables (age, gender, education, race, and income) may be indicators or proxies for personal capabilities, because they may be important for behaviors that depend strongly on particular capabilities [45] (p. 417), [46].

Based on the review of previous works, relationships can be drawn between some personal characteristics of consumers and their willingness to buy and pay more for products and services with environmental management systems [12,32,37,40,47].

Income is usually an important variable in sustainable consumer behavior [36]. The premise is that people with a higher income can afford to spend more on green or sustainable products [34]. Some studies state that consumers' willingness to pay for green initiatives varies according to the hotel type and client segment [48]. Others, such as Strahilevitz and Myers [49], hold that there are significant differences between luxury segments/products and necessary segments/products. Hence, such studies say it is the consumers of the more-expensive products and services who would be willing to pay more for environmental initiatives. In a consumer analysis of 32 hotels, Erickson and Eckert [50] found that the clients who frequented higher-category hotels were those who would be more willing to pay for green practices.

Income is related to education; thus, people with a higher level of education and income are usually more environmentally aware $[36,46,51]$ and; therefore, tend to consume environmentally-friendly 
products more regularly [52]. It is on this basis that the second and third working hypotheses ( $\mathrm{H} 2$ and $\mathrm{H} 3)$, concerning the income level and education level of boutique hotel clients, are proposed:

Hypothesis 2 (H2). Higher-income clients would be willing to pay more to stay at a boutique hotel that has an environmental management system.

Hypothesis 3 (H3). More highly-educated clients would be willing to pay more to stay at a boutique hotel that has an environmental management system.

Age is another variable related to sustainable product consumption [8,12,40,51], especially the age group between 18 and 35. According to Chan [8], young consumers are the most environmentally-conscious consumers. This is because younger generations, especially those born after 1980 and known as millennial, Generation Y, or echo boomers [53], have grown up with the concept of sustainability. Added to this is young people's capacity to access information, which means they make decisions more consciously. These premises set the basis for the fourth working hypothesis $(\mathrm{H} 4)$ :

Hypothesis 4 (H4). Millennial clients would be willing to pay more to stay at a boutique hotel that has an environmental management system.

In connection with gender, studies generally conclude that women tend to display a higher level of awareness and frequently buy green products [54]. Studies on the accommodation industry by Han et al. [12,32] and Chan [8] also conclude that women are more highly predisposed to paying more for accommodation with environmental practices. Accordingly, the fifth working hypothesis (H5) is related to gender:

Hypothesis 5 (H5). Women would be willing to pay more to stay at a boutique hotel that has an environmental management system.

Finally, the papers that examine the number of children of clients, as a determinant variable, are few. According to Diamantopoulos et al. [55], only three studies have investigated the relationship between the number of children of clients and the strength of their environmental awareness and found a positive relationship [56]. The work of Diamantopulos et al. [55]; however, does not find a positive relationship between individuals having children, or not, and individuals' environmental behavior. The sixth working hypothesis of this work is formulated on the basis of the number of children of clients (H6):

Hypothesis 6 (H6). Clients with children would be willing to pay more to stay at a boutique hotel that has an environmental management system.

\section{Methods}

\subsection{Data and Samples}

The data from boutique hotel owner/managers: As there is no formal listing of boutique hotels in Spain, the most appropriate sample obtained was selected from the main commercial platform site (Rusticae). In the study carried out by Lim and Endam [57], the authors also used the information provided by the main boutique hotel consortia in the UK. As mentioned before, rusticae.com contains 197 boutique hotels; boutiquehotel.me provides 285 boutique hotels in Spain; selectahotels.com provides 220 boutique hotels; and greatsmallhotels.com provides 333 hotels. For this paper, the data provided by Rusticae were used in the sample. The main reasons for choosing this platform are; (i) it is the first platform in Spain (since 1997) that offers charming hotels; and (ii) it is the best positioned and most well known in this market segment. The data were gathered by two procedures: 
- An e-questionnaire, distributed among the establishments belonging to this club for charming accommodation (a category that includes boutique hotels), with the object of determining whether each establishment has a quality certificate. All the hotels had the same participation probability, and the percentage of responses obtained was; therefore, considered a random sample. This type of sampling is useful for cases like ours, where the target population is small, and all the elements that are part of it are known.

- In parallel, the websites of the establishments in question were examined in relation to their environmental certificates by direct observation.

The boutique hotel questionnaire had three blocks of questions. The first block addressed facts related to the date when the establishment started business, the hotel's capacity, and its location. The second block asked whether the establishment employed any environmental management system. The last block asked for the gender and position of the person answering the questionnaire. In the questionnaire, and afterward during a telephone follow-up, emphasis was placed on the need for the answers to be given by the hotel manager or owner.

The hotel websites were subjected to direct observation in parallel, looking for environmental seals or certificates or other seals or certificates earned by the establishment.

The definitive hotel sample was made up of answers to 73 valid questionnaires ( $45.6 \%$ of the total population); the target population of the study was all boutique hotels in Spain belonging to a quality club for charming accommodation. The fieldwork was conducted in March and April 2014. Random sampling was used, and the sampling error found was $\pm 8.5 \%$ (with a confidence interval of $95 \%, p=q=50 \%$ ).

Data on the demand were obtained by launching an e-questionnaire addressed to boutique hotel clients, who were asked various question related to their level of environmental awareness and their willingness to pay more for a boutique hotel with an environmental management system. The sampling method was not random. Rather, the exponential version of snowball sampling was used. With this version, each participant invites more individuals to participate. This technique was chosen, because it provides ways of communicating with populations that are hard to reach [58]. This refers to groups that are difficult to access because of their economic position or geographical location or due to the lack of institutional ways to identify them. In our case, it was difficult, if not impossible, to identify all the tourists that had ever stayed at a boutique hotel. Therefore, the population was unknown, and it was impossible to apply a probabilistic sampling method. The main limitation of snowball sampling is its sensitivity to sampling biases. Sampling biases may occur when the initial group selection is not diverse enough. In order to reduce this limitation in our research, two boutique hotels were asked for information on the main characteristics of their clients (age, economic status, travel profile, main motivations, etc.). The initial group was created using this information, and the rest of groups that were generated had the same characteristics, based on the information provided by the hotels. Despite the limitations of this type of sampling, it is considered an appropriate tool for exploring consumers' willingness to pay more for a boutique hotel that has an environmental management system.

The client questionnaire was divided into three parts. The first defined what a boutique hotel was and asked if the participant had ever stayed at such an establishment (answers were only accepted from clients who had stayed at a boutique hotel at least twice). The second part included items that evaluate the participants' environmental awareness level by determining the importance that participants attached to saving energy, saving water and treating waste. The third part explained what an environmental management system is and asked if the participants would be willing to pay more for a boutique hotel that has such a system. Where the answer was "yes", participants were asked what extra percentage they would pay over the price of 100 euros, which is the mean price of a standard double room for one night. The last block included sociodemographic questions concerning things, such as gender, age, children, education, and net annual income (Table 1). 
Table 1. Client questionnaire question blocks.

\begin{tabular}{|c|c|}
\hline $\begin{array}{l}\text { Question Blocks. Items. } \\
\end{array}$ & References \\
\hline $\begin{array}{l}\text { Boutique hotel definition. (Answer this questionnaire only if you have stayed at least twice in } \\
\text { this type of establishment) }\end{array}$ & {$[15,19,23,25]$} \\
\hline Environmental awareness (scale $0-10)$ & \multirow{7}{*}[10,12,13,28,33,57]{} \\
\hline Steps to save energy & \\
\hline Steps to save water & \\
\hline Steps to manage waste & \\
\hline Willingness to pay more & \\
\hline $\begin{array}{l}\text { Willingness to pay more for a hotel with an environmental management } \\
\text { system: Yes/No }\end{array}$ & \\
\hline $\begin{array}{l}\text { - How much extra would you pay over the mean price of a standard double room, } \\
\text { which is } 100 \text { euros/night, for a hotel with an environmental management system? } \\
0 \% / 5 \% / 10 \% / 15 \%\end{array}$ & \\
\hline Sociodemographic variables & \multirow{5}{*}[23,27,33,35,37]{} \\
\hline Gender: Male/Female & \\
\hline Age: $18-25 / 26-35 / 36-45 / 46-55 / 56$ or over & \\
\hline Children: Yes/No & \\
\hline $\begin{array}{l}\text { Annual net income: Under } 12,000 \text { euros/12,001-15,000 euros/15,001-18,000 } \\
\text { euros/18,001-25,000 euros/25,001-30,000 euros/30,001 euros or more }\end{array}$ & \\
\hline
\end{tabular}

Source: Author.

The fieldwork was conducted from December 2014 to June 2015. The final client sample was made up of 340 valid questionnaires. The study's target population was infinite and was made up of boutique lodging clients (clients who had lodged at least twice in boutique hotels).

\subsection{Techniques Employed in the Analysis of Data and Variables}

Statistical and econometric techniques and tools were used to test the hypotheses. First of all, descriptive analysis was applied to the data to yield detailed information on the characteristics of the respondents and determine their willingness to pay more for boutique hotels that have an environmental management system, in terms of mean values and other measures of position and dispersion.

Second, an independence test was used to give statistical significance to the possible relationship between respondents' willingness to pay more and characteristics, such as income, age, children, commitment to the environment, education, and gender. The commitment variable is the result of grouping three items from the questionnaire using the principal component technique, which is appropriate for such cases.

Last, to detect and quantify the influence of the characteristics mentioned above on respondents' willingness to pay more, two different dependence techniques were used, logit regression and linear regression. In both cases, the independent factors or variables were the same; the only thing that changed was the scale of the dependent variable. In the first case, that of logit regression, a nominal scale, and dichotomous variable ( 1 or 0$)$ were used; in the second case, the variable was metric.

The dependent variable was presented with two names and two different scales:

- Willingness to pay more, with a nominal scale $(1=$ yes; $0=$ no). When the variable is 1 , the individual is considered to be willing to pay extra for hotels where there is an environmental management system. Otherwise, the variable is 0 .

- Extra sum to pay, with a metric scale $(0 \%, 5 \%, 10 \%$, and $15 \%)$. In this case, the variable is expressed as a percentage, i.e., the percentage over an established mean price that the individual would be willing to pay for a boutique hotel with an environmental management system.

The independent variables were:

- Education: A dichotomous variable, which is 1, when the respondent has at least an undergraduate degree, and 0 when the respondent's education is less than an undergraduate degree. 
- Gender: A dichotomous variable, which is 1 , when the respondent is a woman, and 0 when the respondent is a man.

- Number of children: A dichotomous variable, which is 1 , when the respondent has at least one child, and 0 when the respondent has no children.

- Income level: A dichotomous variable, which is 1, when the respondent's annual net income is over 25,000€, and 0 when his/her annual net income is less than $25,000 €$.

- Age: A variable, which is 1 , when the respondent is aged 35 or over, and 0 in all other cases.

- Commitment: A latent variable, which is the result of applying the principal component technique to the energy saving, waste management and water saving items on the questionnaire, measured on a Likert scale from 0 to 10.

\section{Results}

The respondents were all Spanish, primarily women (72.9\%) over the age of 35 (50.6\%), with children $(65.3 \%)$, an annual net income of under $€ 25,000$ and an undergraduate or post-graduate education $(55.3 \%)$.

All respondents displayed a strong commitment to the environment, which was measured by considering how they rated saving energy, saving water and managing waste. These three aspects show a mean rating of slightly above 7 . The median values corroborate a strong degree of commitment to the environment, since $50 \%$ gave energy saving a minimum score of 7 . The score was 8 for water saving and waste management. These results seem coherent; as social awareness has existed for a longer time in the latter two cases than in the first case.

When asked if they were willing to pay more, $52.4 \%$ responded in the affirmative, while $47.6 \%$ said that they would not pay more for a hotel with an environmental management system.

These results varied slightly when the respondents were asked about their willingness to pay extra in percentage terms. The results are not contradictory, given that a $5 \%$ increase in the suggested mean price (100 euros) could be accepted, even by those respondents who answered that they would not be willing to pay more.

\subsection{Relationship between the Respondents' Characteristics and Willingness to Pay More}

Before the planned regression analyses were conducted, Pearson's chi-square test was used to find the statistical significance of the bivariate dependence between each of the independent variables and the two proposed dependent variables. Table 2 provides the results found when the contrast was applied to the monthly data.

Table 2. Relationship between the respondents' characteristics and willingness to pay more.

\begin{tabular}{lcccccc}
\hline & \multicolumn{3}{c}{ Willingness to Pay more } & \multicolumn{3}{c}{ Extra Sum } \\
& dof & $\mathbf{X}^{\mathbf{2}}$ & Sig. & dof & $\mathbf{X}^{\mathbf{2}}$ & Sig. \\
\hline Gender & 1 & $3.067^{*}$ & 0.080 & 3 & $6.624^{*}$ & 0.085 \\
Age & 4 & $22.89^{* * *}$ & 0.000 & 12 & $50.57^{* * *}$ & 0.000 \\
Income & 5 & $16.726^{* * *}$ & 0.005 & 15 & $49.59^{* * *}$ & 0.000 \\
Children & 1 & $9.875^{* * *}$ & 0.002 & 3 & $17.439^{* * *}$ & 0.001 \\
Education & 1 & 2.629 & 0.105 & 3 & $15.392^{* * *}$ & 0.002 \\
\hline
\end{tabular}

$\left(^{*}\right) p$-value $<0.10 ;\left({ }^{* *}\right) p$-value $<0.05 ;(* *) p$-value $<0.01$.

As can be observed, all of the considered variables (gender, age, income, children, and education) display a significant relationship of dependence with the extra sum. Likewise, all the independent variables except education display a relationship of dependence with consumers' willingness to pay more. 


\subsection{Influence of the Respondents' Characteristics on Their Willingness to Pay More}

In the dependence comparison, given in the section above, without indicating the direction of causality, a significant relationship of pairwise dependence was found to exist between each of the independent variables and the corresponding dependent variables.

This is the report of the results of the regression study (linear and logit regression), where all variables were included simultaneously, with the goal, not of predicting, but rather of identifying the direction and intensity of the causal relationships between the independent variables and the dependent variables. In this sense, an attempt was made to detect what user characteristics influence a user's willingness to pay more and how much more they would be willing to pay for a boutique hotel with environmental management.

Both analyses detected that some factors or characteristics of the respondents, which displayed a bivariate dependence with each of the dependent variables, ceased to be influential when a joint analysis was conducted.

Table 3 furnishes the results of the logistic regression, which was run to detect which variables influence consumers' willingness to pay more. The adjusted model, which is significant according to the Hosmer-Lemeshow test $\left(X^{2}=11.079\right.$, dof $=8$ and $p$-value $\left.=0.197\right)$, indicates that the variables of gender, education, and children do not influence the dependent variable, "willingness to pay more". In light of these results, research hypotheses 3,5, and 6 are unacceptable.

Table 3. Results of logistic regression.

\begin{tabular}{lcccc}
\hline \multicolumn{1}{c}{ Variables } & Coefficient & Wald & Sig. & Exp (B) \\
\hline Constant & 0.122 & 0.152 & 0.697 & 1.130 \\
Gender & 0.347 & 1.430 & 0.323 & 1.415 \\
Age & -0.967 & 6.761 & $0.009 * *$ & 0.380 \\
Income & 0.577 & 2.878 & $0.090^{*}$ & 1.781 \\
Children & -0.063 & 0.034 & 0.854 & 0.939 \\
Education & -0.059 & 0.049 & 0.824 & 0.943 \\
Commitment & 1.164 & 52.893 & $0.000^{* * *}$ & 3.202 \\
\hline
\end{tabular}

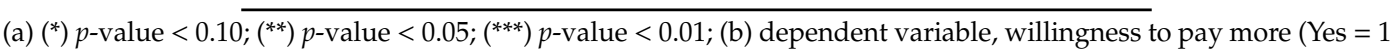
and No $=0)$; (c) Hosmer and Lemeshow: chi-square $=11.079$; dof $=8$; sig.: 0.197.

With respect to the respondents' age, being a millennial is an explanatory variable of consumers' willingness to pay more. A negative sign of the coefficient indicates that an age of 35 or over reduces the likelihood that one will be willing to pay more. This; therefore, indicates that an age of under 35 would increase the likelihood that one will be willing to pay more. This result allows hypothesis 4 to be accepted.

Clients' net income is also determinant of their willingness to pay more. Earning more than 25,000€ net per year increases one's likelihood of being willing to pay more for a hotel with environmental management, which indicates that hypothesis 2 can be validated.

Hypothesis 1 is validated as well, because the commitment variable is significant, and the sign of its coefficient is positive. This indicates that the stronger one's environmental awareness, the greater the likelihood that one will be willing to pay more.

With the objective of quantifying the extra sum that respondents would be willing to pay and corroborating the results yielded by the logistic regression analysis, a linear regression analysis was run, the results of which are given in Table 4 . It can be deduced, from the table, that gender, education, and children are not determinant factors of consumers' willingness to pay extra on top of an established mean price, as found by logistic regression. 
Table 4. Linear regression.

\begin{tabular}{lccccc}
\hline Variables & Coefficient & Standardized Coefficient & Sig. & Tolerance & VIF \\
\hline Constant & 4.766 & - & $0.000^{* * *}$ & & \\
Gender & 0.699 & 0.079 & 0.103 & 0.958 & 1.044 \\
Age & -2.053 & -0.261 & $0.000^{* * *}$ & 0.460 & 2.173 \\
Income & 1.001 & 0.123 & $0.041^{* *}$ & 0.618 & 1.619 \\
Children & -0.017 & -0.002 & 0.973 & 0.611 & 1.637 \\
Education & -0.265 & -0.033 & 0.499 & 0.911 & 1.097 \\
Commitment & 1.620 & 0.411 & $0.000^{* * *}$ & 0.925 & 1.081 \\
\hline
\end{tabular}

(a) $\left.{ }^{*}\right) p$-value $\left.<0.10 ;{ }^{* *}\right) p$-value $<0.05 ;\left(^{* * *}\right) p$-value $<0.01$. (b) Dependent variable: extra sum to pay. (c) Tolerance $(>0.10)$, and VIF (Variance Inflation Factor) $(<10)$ indicate that there are no serious multicollinearity problems. (d) The Durbin-Watson statistic (1.871) indicates that there is no first-order autocorrelation. (e) $R^{2}=0.260$.

Age, income, and commitment to the environment; however, do influence the extra sum that clients would be willing to pay for a hotel with environmental management. Age has a negative influence, such that, the older the client, the less the client would be willing to pay. Income and commitment have a positive influence (i.e., the higher the income and the stronger the commitment, the larger the extra sum clients would be willing to pay for a boutique hotel with environmental management). Finally, and from the quantitative perspective, $52.4 \%$ of the respondents said that they would pay more for a hotel with an environmental management system. Moreover, when the clients were asked about their willingness to pay extra in percentage terms, all of them answered that a $5 \%$ increase (on top of the suggested mean price of 100 euros) could be accepted, including those respondents who answered that they would not be willing to pay more.

\section{Discussion, Conclusions and Implications}

\subsection{Discussion and Conclusions}

The following section highlights the most significant facts revealed by the research, which pave the way for the principal findings and their implications for the boutique accommodation industry. The first conclusion, following from the review of the previously existing literature, is related to the rapid proliferation of voluntary standards and environmental management systems in the accommodation industry over the last three decades. Small hotels, a category that includes boutique hotels (less than 100 rooms), can, like major corporations, be motivated by economic concerns and/or the owner's or manager's ethical standards to incorporate environmental management systems.

Sustainable hotel practices are; however, widely unknown to tourists due to the dizzying variety of ecolabels in the tourism industry. Bewildered tourists find it hard to know which labels to trust and exactly what each label means [59]. The study carried out by Bohdanowicz [10] on European hoteliers' environmental attitudes confirms consumers' apparent indifference. If costumers were to demand more environmentally-sound performance from hotels, it would cause a substantial change [10] (p. 193). This is produced as a consequence of the reduction of operational costs that follows from the demand of customers, which are strong incentives for hoteliers to undertake more environmentally-friendly initiatives. The study carried out by Deng, Ryan and Mountinho [60] concludes that, in the case of Canadian hoteliers, hotels tend to concur with environmental protection policies, generally irrespective of profitability.

Burgin and Hardiman [61] (p. 31) indicate that small business tourism and hospitality operators who choose to pursue eco-accreditation need to clearly explain to consumers what benefits their choice will have for the environment and recognize that merely displaying a brand logo will not inspire credibility. This may require, for example, providing detailed information on websites for potential visitors to study in making their choice of hotel or information booklets at the point of sale.

In this sense, it is important to ascertain whether the clients of these establishments recognize the importance of the existence of environmental management systems and whether they are willing to 
pay extra for such systems. This research has reviewed many studies and theories relating to the topic of consumers' willingness to pay more for hotels that have sustainable practices. Most of the studies reveal that travelers' level of environmental awareness can influence their willingness to pay more (WTP) for sustainable or environmentally-certified products. For this reason, the research reported in this paper focused on clients' willingness to pay more for an environmental management system. The conclusions drawn from the findings rest on the results of an analysis of boutique hotels in Spain. First, the number of boutique hotels with environmental certification is still very low, which is due primarily to the cost of certification and low awareness among entrepreneurs. Secondly, concerning demand, over half of the respondent clients of boutique hotels would be willing to pay more to stay at a boutique hotel with an environmental management system. A more in-depth study was conducted to break the demand down into segments, according to consumers' readiness to pay, and to ascertain the variables that are determinants of consumers' willingness to pay. The results reflect, first, that gender, education, and children are not determinant of consumers' willingness to pay extra for a boutique hotel with a system of this type. However, respondents' age and income, as well as the strength of their environmental commitment, are determinants.

Clients regarded as millennials (clients under the age of 35) present a higher likelihood of having a willingness to pay more. This may be due to the fact that this segment of the demand is more familiar with the concepts associated with sustainability and recycling, which are coetaneous with millennials. These results are in line with those of Coddington [62]; D'Souza et al. [63]; and Thieme et al. [54]. They concluded that younger consumers are more concerned with environmental issues than older consumers. In addition to age, clients' net income is also determinant of their willingness to pay more, and the results show that respondents with a net annual income of over 25,000 euros are more likely to pay more for a hotel with environmental management. Likewise, clients with a stronger commitment to the environment present a higher likelihood of being willing to pay more to stay in a hotel with an environmental management system. The research also finds that being a millennial earning over 25,000 euros and being committed to the environment are determinant of client's not only having a willingness to pay more, but also having a willingness to accept a greater increase in the price.

\subsection{Implications}

Our results have both theoretical and practical implications. From the theoretical perspective, and according to the theory of planned behavior (TPB), an intention is considered an immediate antecedent of behavior. In this work, the results support the principles established by TPB and applied in several studies [33-35,40]. These results show that commitment to the environment influences the extra sum that clients would be willing to pay for a hotel with environmental management. Thus, intention indicates an individual's readiness/willingness to engage in a particular behavior [42]. According to this theory and the results, if an individual's attitude is in favor of green behavior, green behavior is the perceived social norm, and the individual believes the behavior to be rather easy to perform, the individual's intention to perform green behavior should increase [41]. In addition, the incorporation of other variables, such as age or income, facilitate a better comprehensive understanding of green hotel customers' decision-making process [35,40].

Concerning the practical implications, instituting an environmental management system at a boutique hotel is advantageous for entrepreneurs, both ethically and economically, and it is good in terms of the recognition that it earns the hotel, primarily among the hotel's younger and more environmentally-conscious clients. If this feature is adequately communicated over direct channels (the hotel website) and indirect channels (marketing platforms, specialized travel agencies, and other channels), it can function to differentiate the hotel from competitors in the same sector and focus on younger clients who have a strong environmental commitment and strong purchasing power. The findings of Kim and Han [33] also suggested that marketers should develop efficient strategies for enhancing their image by advertising their environment-friendly practices to visiting and potential customers using multiple information sources. These various efforts would contribute to instilling 
in customers a strong intention to repurchase a green hotel product. Additionally, the study carried out by Can, Turker, Ozturk and Alaeddinoglu [64] concerning tourists' perception of green practices in eco-friendly hotels in Antalya (Turkey), which considered 67 hotels (two of which were boutique hotels), draws the same conclusion. They suggest that hotels should publicize their commitment to the environment through EMSs on their websites and also on other platforms, such as TripAdvisor.com. Additionally, Chan [8], concludes that the internet is an effective channel for marketing a hotel's green initiatives directly to customers, and green hotels can elevate industry members' image and reputation in order to attract green tourists who demand green accommodation when travelling.

\section{Limitations and Future Lines}

If the sample was more representative, the research conclusions could be extended to the entire set of boutique hotels and all boutique hotel clients. In the case of boutique hotel clients, the sampling method does not guarantee representativeness. The main limitation of snowball sampling is its sensitivity to sampling biases. Sampling biases may occur when the initial group selection is not diverse enough. In order to reduce this limitation in our research, a pair of boutique hotels were asked for information concerning the main characteristics of their clients (age, economic status, travel profile, main motivations, etc.). As mentioned before, the initial group was created on the basis of this information, and the rest of the groups that were generated had the same characteristics, based on the information provided by the hotels.

Additionally, all study participants were Spanish. It would be helpful to better understand consumers' WTP for sustainable practices on the basis of their nationality by obtaining a more varied and balanced distributed data set. Even so, the importance of incorporating environmental management systems in hotels of this type remains clear. To overcome the limitations of the present research, further research will be conducted in the future to secure a client sample that is better balanced in terms of age, gender, and income and to expand the sample of participating hotels. Additionally, when this type of establishment incorporates EMSs, the price levels of hotels, with and without EMSs, can be analyzed, which would facilitate the analysis of this phenomenon from the supply perspective.

Author Contributions: The individual contribution and responsibilities of the authors were as follows: Data curation, C.L.-I.; formal analysis, L.F.-M.; investigation, C.L.-I. and A.M.-M.; methodology, C.L.-I.; resources, T.V.-M.; supervision, A.M.-M. and T.V.-M.; validation, L.F.-M. and A.M.-M.; writing-original draft, L.F.-M.; writing-review and editing, T.V.-M.

Funding: This research received no external funding.

Conflicts of Interest: The authors declare no conflict of interest.

\section{References}

1. Molina-Azorín, J.F.; Claver-Cortés, E.; Pereira-Moliner, J.; Tarí, J.J. Environmental Practices and Firm Performance: An Empirical Analysis in the Spanish Hotel Industry. J. Clean. Prod. 2009, 17, 516-524. [CrossRef]

2. Buffa, F.; Franch, M.; Martini, U.; Tamanini, A. Hotel Profiles Based on Environmental Management Practices: Evidence from a Study at an Alpine Destination. Sustainability 2018, 10, 4531. [CrossRef]

3. Ayuso, S. Comparing Voluntary Policy Instruments for Sustainable Tourism: The Experience of the Spanish Hotel Sector. J. Sustain. Tour. 2007, 15, 144-159. [CrossRef]

4. Kleinrichert, D.; Ergul, M.; Johnson, C.; Uydaci, M. Boutique Hotels: Technology, Social Media and Green Practices. J. Hosp. Tour. Technol. 2012, 3, 211-225. [CrossRef]

5. Tzschentke, N.; Kirk, D.; Lynch, P.A. Reasons for Going Green in Serviced Accommodation Establishments. Int. J. Contemp. Hosp. Manag. 2004, 16, 116-124. [CrossRef]

6. Rivera, J. Assessing a Voluntary Environmental Initiative in the Developing World: The Costa Rican Certification for Sustainable Tourism. Policy Sci. 2002, 35, 333-360. [CrossRef]

7. Johnson, C. Sustainable Development in Hotels: Industry Applications and Case Studies. Travel Tour. Anal. 2002, 8, 1-26. 
8. SW Chan, E. Gap Analysis of Green Hotel Marketing. Int. J. Contemp. Hosp. Manag. 2013, 25, 1017-1048. [CrossRef]

9. Buckley, R.; Araujo, G. Environmental Management Performance in Tourism Accommodation. Ann. Tour. Res. 1997, 24, 465-469. [CrossRef]

10. Bohdanowicz, P. European Hoteliers' Environmental Attitudes: Greening the Business. Cornell Hotel Restaur. Adm. Q. 2005, 46, 188-204. [CrossRef]

11. Dimara, E.; Manganari, E.; Skuras, D. Consumers' Willingness to Pay Premium for Green Hotels: Fact or Fad? In Proceedings of the International Marketing Trends Conference, Paris, France, 22-24 January 2015; pp. 1-16.

12. Han, H.; Hsu, L.-T.J.; Lee, J.-S. Empirical Investigation of the Roles of Attitudes toward Green Behaviors, Overall Image, Gender, and Age in Hotel Customers' Eco-Friendly Decision-Making Process. Int. J. Hosp. Manag. 2009, 28, 519-528. [CrossRef]

13. Lee, J.-S.; Hsu, L.-T.; Han, H.; Kim, Y. Understanding How Consumers View Green Hotels: How a Hotel's Green Image Can Influence Behavioural Intentions. J. Sustain. Tour. 2010, 18, 901-914. [CrossRef]

14. Aggett, M. What Has Influenced Growth in the UK's Boutique Hotel Sector? Int. J. Contemp. Hosp. Manag. 2007, 19, 169-177. [CrossRef]

15. Balekjian, C.; Sarheim, L. Boutique Hotels Segment-The Challenge of Standing out from the Crowd; HVS: London, UK, 2011.

16. Callan, R.J.; Fearon, R. Town House Hotels-an Emerging Sector. Int. J. Contemp. Hosp. Manag. 1997, 9, 168-175. [CrossRef]

17. Drewer, P. Key Note Market Report Plus, 2005: Hotels. Key Note, Hampton. Available online: http: //ww.keynote.co.uk (accessed on 30 November 2005).

18. Taylor, R. Developers Check into Boutique Hotels. National Real Estate Investor, 1 October 2004; 12.

19. Caterer Search. Townhouse and Boutique Hotels Lead Performance of UK Hotels in 2016. The Caterer, 10 April 2017.

20. National Statistics Institute of Spain. Estadística de Movimientos Turísticos En Fronteras (FRONTUR) December, 2017. Provisional Data; National Statistics Institute of Spain: Madrid, Spain, 2017.

21. World Tourism Organization (UNWTO); Organization of American States (OAS). Tourism and the Sustainable Development Goals—Good Practices in the Americas; World Tourism Organization (UNWTO): Madrid, Spain, 2018; Available online: https://www.oas.org/en/sedi/desd/CT/Documents/OAS_UNWTO_9789284419685.pdf (accessed on 25 January 2018). [CrossRef]

22. Ivars, J.A. Planificación y Gestión Del Desarrollo Turístico Sostenible: Propuestas Para La Creación de Un Sistema de Indicadores $N^{\circ} 1$; Instituto Universitario de Geografía, Universidad de Alicante: Alicante, Spain, 2001.

23. Boutique \& Lifestyle Lodging Association. BLLA. 2014. Available online: https://blla.org/about-blla/ (accessed on 25 November 2015).

24. Mcintosh, A.J.; Siggs, A. An Exploration of the Experiential Nature of Boutique Accommodation. J. Travel Res. 2005, 44, 74-81. [CrossRef]

25. Rowe, M. Defining Boutique Chic. Lodg. Hosp. 2003, 59, 34.

26. Hosteltur. Los Hoteles Boutique Crecen En España y En Europa (Boutique Hotels Grow in Spain and InEurope). 2006. Available online: https://www.hosteltur.com/38272_hoteles-boutique-crecen-ms-espaa-europa.html (accessed on 30 June 2015).

27. Lwin, M.; Phau, I. Effective Advertising Appeals for Websites of Small Boutique Hotels. J. Res. Interact. Mark. 2013, 7, 18-32. [CrossRef]

28. Boley, B.B.; Uysal, M. Competitive Synergy through Practicing Triple Bottom Line Sustainability: Evidence from Three Hospitality Case Studies. Tour. Hosp. Res. 2013, 13, 226-238. [CrossRef]

29. Masau, P.; Prideaux, B. Sustainable Tourism: A Role for Kenya's Hotel Industry. Curr. Issues Tour. 2003, 6, 197-208. [CrossRef]

30. Ollero, J.L.S.; Mera, A.J.M.; Pozo, A.G. Análisis de La Incidencia de Las Certificaciones de Calidad Sobre La Productividad de Los Hoteles En Andalucía. UCJC Bus. Soc. Rev. 2014, 44, 88-103.

31. Kuminoff, N.V.; Zhang, C.; Rudi, J. Are Travelers Willing to Pay a Premium to Stay at a "green" Hotel? Evidence from an Internal Meta-Analysis of Hedonic Price Premia. Agric. Resour. Econ. Rev. 2010, 39, 468-484. [CrossRef] 
32. Han, H.; Hsu, L.-T.J.; Lee, J.-S.; Sheu, C. Are Lodging Customers Ready to Go Green? An Examination of Attitudes, Demographics, and Eco-Friendly Intentions. Int. J. Hosp. Manag. 2011, 30, 345-355. [CrossRef]

33. Kim, Y.; Han, H. Intention to Pay Conventional-Hotel Prices at a Green Hotel-A Modification of the Theory of Planned Behavior. J. Sustain. Tour. 2010, 18, 997-1014. [CrossRef]

34. Straughan, R.D.; Roberts, J.A. Environmental Segmentation Alternatives: A Look at Green Consumer Behavior in the New Millennium. J. Consum. Mark. 1999, 16, 558-575. [CrossRef]

35. Laroche, M.; Bergeron, J.; Barbaro-Forleo, G. Targeting Consumers Who Are Willing to Pay More for Environmentally Friendly Products. J. Consum. Mark. 2001, 18, 503-520. [CrossRef]

36. Do PacO, A.; Raposo, M. “Green” Segmentation: An Application to the Portuguese Consumer Market. Mark. Intell. Plan. 2009, 27, 364-379. [CrossRef]

37. Kang, K.H.; Stein, L.; Heo, C.Y.; Lee, S. Consumers' Willingness to Pay for Green Initiatives of the Hotel Industry. Int. J. Hosp. Manag. 2012, 31, 564-572. [CrossRef]

38. Gupta, S.; Ogden, D.T. To Buy or Not to Buy? A Social Dilemma Perspective on Green Buying. J. Consum. Mark. 2009, 26, 376-391. [CrossRef]

39. Gupta, S. To Pay or Not to Pay a Price Premium for Corporate Social Responsibility: A Social Dilemma and Reference Group Theory Perspective. Acad. Mark. Stud. J. 2015, 19, 24.

40. Han, H.; Hsu, L.-T.J.; Sheu, C. Application of the Theory of Planned Behavior to Green Hotel Choice: Testing the Effect of Environmental Friendly Activities. Tour. Manag. 2011, 31, 325-334. [CrossRef]

41. Jackson, A.E. Hotel Guests' Intentions to Choose Green Hotels. Ph.D. Thesis, University of South Carolina, Columbia, SC, USA, 2010. Available online: https://scholarcommons.sc.edu/etd/1489/ (accessed on 20 June 2015).

42. Ajzen, I. The Theory of Planned Behavior. Organ. Behav. Hum. Decision Process. 1991, 50, 179-211. [CrossRef]

43. Jauhari, V.; Manaktola, K. Exploring Consumer Attitude and Behaviour towards Green Practices in the Lodging Industry in India. Int. J. Contemp. Hosp. Manag. 2007, 19, 364-377.

44. Moisander, J. Motivational Complexity of Green Consumerism. Int. J. Consum. Stud. 2007, 31, 404-409. [CrossRef]

45. Stern, P.C. New Environmental Theories: Toward a Coherent Theory of Environmentally Significant Behavior. J. Soc. Issues 2000, 56, 407-424. [CrossRef]

46. Yu, B.; Cai, Y.; Jin, L.; Du, B. Effects on Willingness to Pay for Marine Conservation: Evidence from Zhejiang Province, China. Sustainability 2018, 10, 2298. [CrossRef]

47. Chang, L.-H.; Hsiao, Y.-C.; Nuryyev, G.; Huang, M.-L. People's Motivation, Constraints and Willingness to Pay for Green Hotels. Eur. J. Tour. Res. 2015, 9, 67-77.

48. Bhattacharya, C.B.; Sen, S. Doing Better at Doing Good: When, Why, and How Consumers Respond to Corporate Social Initiatives. Calif. Manag. Rev. 2004, 47, 9-24. [CrossRef]

49. Strahilevitz, M.; Myers, J.G. Donations to Charity as Purchase Incentives: How Well They Work May Depend on What You Are Trying to Sell. J. Consum. Res. 1998, 24, 434-446. [CrossRef]

50. Erickson, R.; Eckert, K. The Elderly Poor in Downtown San Diego Hotels. Gerontologist 1977, 17, 440-446. [CrossRef]

51. Kanchanapibul, M.; Lacka, E.; Wang, X.; Chan, H.K. An Empirical Investigation of Green Purchase Behaviour among the Young Generation. J. Clean. Prod. 2014, 66, 528-536. [CrossRef]

52. Ashok, S.; Tewari, H.; Behera, M.; Majumdar, A. Development of Ecotourism Sustainability Assessment Framework Employing Delphi, C\&I and Participatory Methods: A Case Study of KBR, West Sikkim, India. Tour. Manag. Perspect. 2017, 21, 24-41.

53. Pomarici, E.; Vecchio, R. Millennial Generation Attitudes to Sustainable Wine: An Exploratory Study on Italian Consumers. J. Clean. Prod. 2014, 66, 537-545. [CrossRef]

54. Thieme, J.; Royne, M.B.; Jha, S.; Levy, M.; Barnes McEntee, W. Factors Affecting the Relationship between Environmental Concern and Behaviors. Mark. Intell. Plan. 2015, 33, 675-690. [CrossRef]

55. Diamantopoulos, A.; Schlegelmilch, B.B.; Sinkovics, R.R.; Bohlen, G.M. Can Socio-Demographics Still Play a Role in Profiling Green Consumers? A Review of the Evidence and an Empirical Investigation. J. Bus. Res. 2003, 56, 465-480. [CrossRef]

56. Jackson, J.E. Measuring the Demand for Environmental Quality with Survey Data. J. Polit. 1983, 45, 335-350. [CrossRef] 
57. Mun Lim, W.; Endean, M. Elucidating the Aesthetic and Operational Characteristics of UK Boutique Hotels. Int. J. Contemp. Hosp. Manag. 2009, 21, 38-51. [CrossRef]

58. Johnston, L.G.; Sabin, K. Sampling Hard-to-Reach Populations with Respondent Driven Sampling. Methodol. Innov. Online 2010, 5, 38-48. [CrossRef]

59. Buckley, R. Tourism Ecolabels. Ann. Tour. Res. 2002, 29, 183-208. [CrossRef]

60. Deng, S.L.; Ryan, C.; Moutinho, L. Canadian Hoteliers and Their Attitudes towards Environmental Issues. Int. J. Hosp. Manag. 1992, 11, 225-237. [CrossRef]

61. Burgin, S.; Hardiman, N. Eco-Accreditation: Win-Win for the Environment and Small Business? Int. J. Bus. Stud. 2010, 18, 23.

62. Coddington, W. Environmental Marketing: Positive Strategies for Reaching the Green Consumer; McGraw-Hill Companies: New York, NY, USA, 1993.

63. D'Souza, C.; Taghian, M.; Lamb, P.; Peretiatko, R. Green Decisions: Demographics and Consumer Understanding of Environmental Labels. Int. J. Consum. Stud. 2007, 31, 371-376. [CrossRef]

64. Can, A.S.; Turker, N.; Ozturk, S.; Alaeddinoglu, F. Tourists'perception of green practices in eco-friendly hotels: A case study from the antalya region of turkey. J. Tour. Chall. Trends 2014, 7, 9.

(C) 2019 by the authors. Licensee MDPI, Basel, Switzerland. This article is an open access article distributed under the terms and conditions of the Creative Commons Attribution (CC BY) license (http://creativecommons.org/licenses/by/4.0/). 